fibers, which carry nociceptive information in the sympathetic pain pathway, can be blocked by a high-frequency SCS.

The present report describes the first patient with intractable pain due to sickle cell disease who was treated with a highfrequency SCS successfully. For patients in whom all available treatments have failed or who have an increased risk for more invasive surgical interventions, the SCS might be a therapeutic alternative.

Keywords: Chronic pain, Sickle cell disease, Spinal cord stimulation

Anahtar Sözcükler: Kronik ağrı, Orak hücre hastalığı, Spinal kord stimülatörü

Informed Consent: It was received.

Conflict of Interest: The authors of this paper have no conflicts of interest, including specific financial interests, relationships, and/ or affiliations relevant to the subject matter or materials included.

\section{References}

1. Kumar K, Hunter G, Demeria D. Spinal cord stimulation in treatment of chronic benign pain: challenges in treatment planning and present status, a 22-year experience. Neurosurgery 2006;58:481-496.

2. Ghajar AW, Miles JB. The differential effect of the level of spinal cord stimulation on patients with advanced peripheral vascular disease in the lower limbs. Br J Neurosurg 1996;12:402-408.

3. Hautvast RW, DeJongste MJ, Staal MJ, van Gilst WH, Lie KI. Spinal cord stimulation in chronic intractable angina pectoris: a randomized controlled efficacy study. Am Heart J 1998;136:1114-1120.

4. Kumar K, Toth C, Nath RK. Spinal cord stimulation for chronic pain in peripheral neuropathy. Surg Neurol 1996;46:363-369.

5. Melzack RA, Wall PD. Pain mechanisms: a new theory. Science 1965;150:971979.

6. Stojanovic M, Abdi S. Spinal cord stimulation. Pain Physician 2002;5:156166.

7. Nebor D, Bowers A, Hardy-Dessources MD, Knight-Madden J, Romana $M$, Reid $H$, Barthélémy JC, Cumming $V$, Hue 0 , Elion J, Reid $M$, Connes $P$; CAREST Study Group. Frequency of pain crises in sickle cell anemia and its relationship with the sympatho-vagal balance, blood viscosity and inflammation. Haematologica 2011;96:1589-1594.

8. Simpson EL, Duenas A, Holmes MW, Papaioannou D, Chilocott J. Spinal cord stimulation for chronic pain of neuropathic or ischaemic origin: systematic review and economic evaluation. Health Technol Assess 2009;13:1-154.

๑Copyright 2018 by Turkish Society of Hematology

Turkish Journal of Hematology, Published by Galenos Publishing House

\title{
Simultaneous Presence of Follicular Lymphoma, Diffuse Large B-cell Lymphoma, and Hodgkin-like Lymphoma
}

\section{Eş Zamanlı Folliküler Lenfoma, Diffüz Büyük B Hücreli Lenfoma ve Hodgkin-Benzeri Lenfoma Varlığı}

(D) Alexandra Papoudou-Bai1, (D) Leonidas Marinos², (D) Konstantina Papathanasiou4, (D) Panagiotis Kanavaros³, (D) Eleni Kapsali4

\author{
1 University of loannina Faculty of Medicine, Department of Pathology, loannina, Greece \\ 2Evangelismos General Hospital, Clinic of Hematopathology, Athens, Greece \\ 3 University of loannina Faculty of Medicine, Department of Anatomy-Histology-Embryology, loannina, Greece \\ 4University of loannina Faculty of Medicine, Department of Hematology, loannina, Greece
}

To the Editor,

Follicular lymphoma (FL) is a relatively indolent B-cell lymphoma that may transform to a higher-grade lymphoma, most commonly diffuse large B-cell lymphoma (DLBCL) [1]. On the other hand, the occurrence of Hodgkin lymphoma $(\mathrm{HL})$ subsequent to $\mathrm{FL}$ as well as composite lymphomas that are composed of $\mathrm{HL}$ and $\mathrm{FL}$ have rarely been recorded $[1,2,3,4,5]$. To the best of our knowledge, this is the first reported case of the simultaneous presence of $\mathrm{FL}, \mathrm{DLBCL}$, and Hodgkin-like lymphoma in a lymph node. A 65-year-old man developed a palpable mass in his left axilla, which grew larger in a period of 2 months. The patient reported no other symptoms and had no notable medical history. Biopsy of the left axillary lymph node revealed grade 3A-FL with areas of DLBCL. DLBCL was also observed in the biopsy of a mass of the thoracic wall, which was near the enlarged axillary lymph node. Moreover, in the lymph node, Hodgkin and Reed-Sternberg (HRS) cells were identified in extrafollicular areas and some neoplastic follicles (Figure 1). Although some scattered eosinophils, plasma 
cells, and histiocytes were observed in the cellular background of the extrafollicular HRS cells, the extent of this cellular infiltrate was less than what would be expected for typical HL (Figure 1). Immunohistochemistry revealed that the follicular neoplastic cells were CD20+, CD10+, BCL6+, BCL2+, PAX-5+, CD30-, CD15-, and MUM1- (Figure 1). The HRS cells were CD30+, CD15+ (20\%), CD20-, CD10-, BCL6-, MUM1+, CD3-, CD4-, CD8-, and weakly PAX-5+ (Figure 1). A few reactive follicles with CD10+, BCL6+, and BCL2- germinal center cells were also observed. EBER-in situ hybridization demonstrated Epstein-Barr virus (EBV) positivity in some cells in a few neoplastic follicles (Figure 1), but not in the DLBCL component or in the HRS cells. The above findings were consistent with the simultaneous presence of $\mathrm{FL}$, DLBCL, and Hodgkin-like lymphoma. Computed tomography (CT) and positron-emission tomography (PET)/CT and bone marrow (BM) biopsy were performed. The lymphoma was assigned stage IV because of BM infiltration. The BM lymphoid infiltration was diffuse (15\%-20\% of the total BM nucleated cells) and composed of medium-sized lymphoid cells with immunophenotype of CD20+, CD10+, BCL6+, PAX-5+, MUM1-, and CD30-. In addition, some cells with the morphology of Hodgkin cells and immunophenotype of CD30+, CD15+, CD45+, CD20-, CD10-, BCL6-, and PAX-5- were also identified in the lymphoid infiltration. The patient subsequently underwent six cycles of

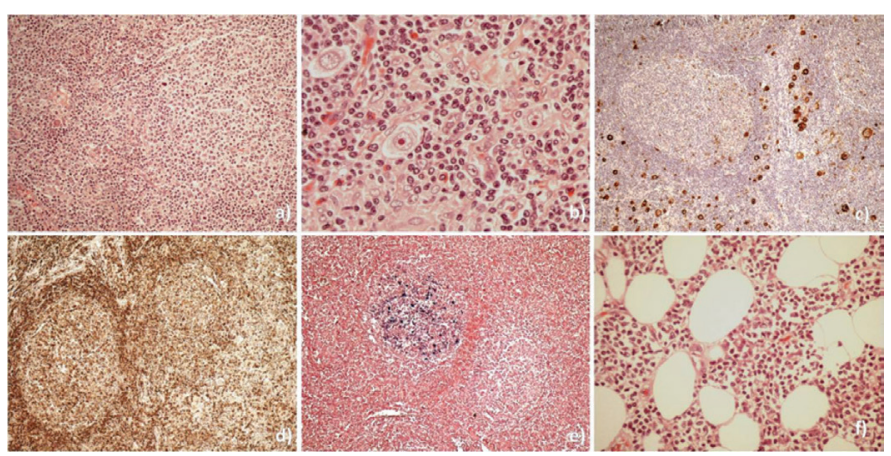

Figure 1. a) Synchronous presence of follicular lymphoma (FL) with Hodgkin-like lymphoma (hematoxylin and eosin staining, $200^{x}$; b) Hodgkin cells admixed with scattered eosinophils, plasma cells, and histiocytes (hematoxylin and eosin staining, 600x); c) CD30+ Hodgkin and Reed-Sternberg cells in the extrafollicular areas surrounding a neoplastic follicle (immunohistochemical staining, 100); d) synchronous presence of FL with Hodgkinlike lymphoma, where the neoplastic follicles express the BCL2 protein (immunohistochemical staining, 100); e) Epstein-Barr virus (EBER)-positive cells in the neoplastic follicles (in situ hybridization, 100×); f) diffuse large B-cell lymphoma (hematoxylin and eosin staining, 400).
rituximab-CHOP chemotherapy without adverse effects. After treatment, the $\mathrm{CT}$ scans and $\mathrm{PET} / \mathrm{CT}$ results were consistent with complete response and BM biopsy showed no lymphoma. He is currently in regular follow-up. In our case, the DLBCL component may correspond to transformation of the FL component, and the EBV-negative Hodgkin-like component may arise from the EBVnegative intrafollicular HRS cells that we detected in the lymph node. The occurrence of $\mathrm{HL}$ subsequent to $\mathrm{FL}$ as well as composite lymphomas consisting of $\mathrm{HL}$ (with classical immunophenotype) and $\mathrm{FL}$ without EBV association were rarely reported $[2,3,4]$. In contrast, Menon et al. [5] described transformation of FL to EBVpositive Hodgkin-like lymphoma. Interestingly, in keeping with the findings of Menon et al. [5], we also observed EBV-positive cells in a few neoplastic follicles. This suggests that EBV infected the cells secondarily in the neoplastic follicles. In conclusion, this is the first reported case of the simultaneous presence of $\mathrm{FL}$, DLBCL, and EBV-negative Hodgkin-like lymphoma.

Keywords: Transformation, Follicular lymphoma, Hodgkin-like lymphoma

Anahtar Sözcükler: Transformasyon, Folliküler lenfoma, Hodgkin-benzeri lenfoma

Informed Consent: It was received.

Conflict of Interest: The authors of this paper have no conflicts of interest, including specific financial interests, relationships, and/or affiliations relevant to the subject matter or materials included.

\section{References}

1. Fischer T, Zing NPC, Chiattone CS, Federico M, Luminari S. Transformed follicular lymphoma. Ann Hematol 2018;97:17-29.

2. Brauninger $A$, Hansmann ML, Strickler JG, Dummer R, Burg G, Rajewsky K, Küppers R. Identification of common germinal-center B-cell precursors in two patients with both Hodgkin's disease and non-Hodgkin's lymphoma. N Engl J Med 1999;340:1239-1247.

3. Marafioti T, Hummel M, Anagnostopoulos I, Foss HD, Huhn D, Stein H. Classical Hodgkin's disease and follicular lymphoma originating from the same germinal center B cell. J Clin Oncol 1999;17:3804-3809.

4. Nakamura $N$, Ohshima $K$, Abe $M$, Osamura Y. Demonstration of chimeric DNA of bcl-2 and immunoglobulin heavy chain in follicular lymphoma and subsequent Hodgkin lymphoma from the same patient. J Clin Exp Hematop 2007;47:9-13.

5. Menon MP, Hutchinson L, Garver J, Jaffe ES, Woda BA. Transformation of follicular lymphoma to Epstein-Barr virus-related Hodgkin-like lymphoma. J Clin Oncol 2013;31:53-56.
Address for Correspondence/Yazışma Adresi: Alexandra PAPOUDOU-BAI, M.D., University of loannina Faculty of Medicine, Department of Pathology, Ioannina, Greece E-mail : apapoudoubai@gmail.com ORCID-ID: orcid.org/0000-0002-3932-6652
Received/Geliş tarihi: May 29, 2018 Accepted/Kabul tarihi: July 04, 2018

DOI: $10.4274 /$ tjh.2018.0183 